WMJ (Warmadewa Medical Journal), Vol. 5 No. 1 Mei 2020, Hal. 16-21

\title{
Correlation between Nutrition Status and Fitness among Ele- mentary School Students in Bali Province
}

\author{
Cok Istri Dewiyani Cakrawati ${ }^{1,3}$, Ni Ketut Sutiari ${ }^{2}$, Ni Luh Putu Suaryani ${ }^{2}$ \\ ${ }^{I}$ Master of Public Health Program, Udayana University, Bali \\ ${ }^{2}$ Department of Public Health and Preventive Medicine, Udayana University, Bali \\ ${ }^{3}$ Bali Provincial Health Service
}

\begin{abstract}
Lack of physical activity and excess energy consumption have an impact on increasing the prevalence of obesity in elementary school children. Furthermore, this condition is often associated with cardiorespiratory fitness. This condition certainly has an impact on increasing the risk of non-communicable diseases. It is necessary to know the nutritional status and physical fitness level in elementary school children so that early intervention can be done to prevent obesity among children. This study uses a cross-sectional study design. The population in this study were elementary school students aged 10-12 years in Bali Province. A total of 704 students were selected by purposive sampling. Data collected included the characteristics of respondents through interview methods, anthropometry measurements (BMI/Age), and fitness measurements. Fitness Tests are carried out using the single test method (a walk/run test as far as 1200 meters). Eligibility criteria are students aged 10-12 years, not in illness/disability, and willing to take a fitness test. Data were analyzed descriptively and analytically using the chi-square method. This study found that nutritional status for very thin, thin, normal, overweight, and obese were $3.6 \%, 19.5 \%, 46.1 \%, 29.6 \%$, and $1.2 \%$, respectively. Meanwhile fitness for less fit, quite fit and fit respectively were $64.1 \%, 22.7 \%$, and $13.15 \%$, respectively. There is a significant relationship obtained between age, sex, and nutritional status with fitness $(\mathrm{p}<0.05)$. It is recommended to improve the nutritional status of overweight and obese students as well as increase physical activity among students to improve their fitness.
\end{abstract}

Keywords: Nutrition Status, Fitness, Elementary School

\section{Abstrak}

[Hubungan Status Gizi Dengan Kebugaran pada Siswa Sekolah Dasar di Provinsi Bali]

Kurangnya aktifitas fisik dan konsumsi energi berlebih berdampak pada peningkatan prevalensi obesitas pada siswa Sekolah Dasar (SD). Selanjutnya kondisi ini sering dikaitkan dengan tingkat kebugaran kardiorespirasi. Kondisi ini tentunya dapat berdampak pada meningkatnya risiko penyakit tidak menular, sehingga dirasakan perlu untuk mengetahui status gizi dan tingkat kebugaran jasmani pada siswa SD agar dapat dilakukan intervensi dini untuk mencegah peningkatan obesitas pada anak. Penelitian ini menggunakan rancangan cross sectional. Populasi dalam penelitian ini adalah siswa SD usia 10-12 tahun di Provinsi Bali. Sebanyak 704 siswa dipilih secara puposive sampling. Data yang dikumpulkan meliputi karakteristik responden melalui metode wawancara, pengukuran status gizi (IMT/U) dan pengukuran kebugaran. Tes Kebugaran dilakukan dengan metode single test (tes jalan/lari sejauh 1200 meter). Kriteria eligibilitas adalah siswa berusia 10-12 tahun, tidak dalam keadaan sakit/ cacat dan bersedia mengikuti tes kebugaran. Data dianalisis secara deskriptif dan analitik menggunakan metode chi square. Pada hasil penelitian ini didapatkan sebagai berikut, status gizi sangat kurus, kurus, normal, overweight dan obesitas masing-masing 3,6\%, 19,5\%, 46,1\%, 29,6\% dan 1,2\%, sedangkan untuk kebugaran sebagai berikut kurang bugar, cukup bugar dan bugar masing-masing 64,1\%, 22,7\%, dan 13,15\%. Didapatkan juga hubungan yang bermakna antara umur, jenis kelamin dan status gizi dengan kebugaran $(p<0,05)$. Disarankan perlu dilakukan perbaikan status gizi pada siswa overweight dan obesitas serta peningkatan aktivitas fisik pada siswa untuk meningkatkan kebugaran.

Kata Kunci: Status Gizi, Kebugaran, Siswa Sekolah Dasar 


\section{BACKGROUND}

Cardiorespiratory fitness and obesity are often associated with reduced risk of death, cardiovascular risk factors ${ }^{1,2}$, and academic achievement ${ }^{3,4}$. But research showed that there has been a significant decrease in cardiorespiratory fitness among students. A longitudinal study conducted by Gerson et al (2013) showed a decrease in cardiorespiratory fitness among students in Brazil over the past 30 years ${ }^{6,5}$.

Besides, the prevalence of obesity by a birth cohort was increasing from 1980$2015^{6}$. Increased prevalence of obesity is a major public health challenge worldwide ${ }^{8}$. The high prevalence of obesity does not only occur in developed countries but also developing countries 9. According to the results of the Basic Health Research (Riskesdas), the prevalence of obesity in Indonesia was reported to increase from $10.5 \%$ in $2007,14.8 \%$ in 2013 to $21.8 \%$ in $2018^{10}$. The prevalence of overweight and obesity in Bali Province is reported to have increased from 2013 to 2018. The prevalence of overweight and obesity in children aged 5-12 years was $12.8 \%$ and $8.8 \%$ in 2013 , respectively. Whereas the prevalence of overweight and obesity increased to $13.0 \%$ and $10.6 \%$ in 2018 , respectively ${ }^{10}$.

On the other hand, a decrease in physical activity was reported in the population aged $\geq 10$ years. Riskesdas results revealed that the proportion of the Indonesian population with less physical activity was $26.1 \%$ in 2013 and was increasing to $33.5 \%$ in 2018. The proportion of the population with less activity was $14.2 \%$ in 2013 and increased to $20.6 \%$ in 2018 in Bali Province 10 .

Obesity and physical activity are often associated with cardiorespiratory fitness. Cardiorespiratory fitness measurement with maximal and submaximal methods is an indirect measurement often used to get a picture of cardiorespiratory fitness prevalence. Fitness measurement in Indonesia was carried out in 17 provinces by the Center for Physical Quality Development, the Ministry of National Education in 2010 on 12,240 school children using the Indonesian Physical Fitness Test (TKJI). The measurement results showed $45 \%$ of students are not fit ${ }^{11}$.

The correlation between obesity and fitness has been widely investigated but literature studies show inconclusive results 12,13. Given an increasing proportion of obesity and decreasing physical activity in Bali province, it is necessary to determine the cardiovascular fitness among elementary school students and its relation to nutritional status.

\section{METHODS}

A cross-sectional design was used in this study. Secondary data from fitness measurements conducted by the Bali Provincial Health Service in 2018 was analyzed. Nine schools were selected by the Department of Youth and Sports Education in 9 districts/cities. A total of 740 elementary school students were selected purposively.

Students with physical limitations and do not meet the PAR-Q and You test requirements were not included in the fitness measurements. All students who took part in the measurement were confirmed to be in good health, free from musculoskeletal dysfunction and cardiovascular diseases.

Fitness and anthropometric assessment were conducted on the same day. Cardiorespiratory fitness was measured by the submaximal method "Single test" (running or walking on 1,200 meters distance) following the ability of respondents and without being forced. Running time was recorded to determine students' fitness status. Fitness status is classified based on School Children Fitness Measurement Guidelines ${ }^{13}$.

Height and weight measurements were taken using a calibrated Scmic ZT 120 GEA to calculate BMI. Nutritional status was determined based on BMI/Age 


\section{WMJ (Warmadewa Medical Journal), Vol. 5 No. 1, Mei 2020, Hal. 18}

(Ministry of Health, 2011). The data obtained were analyzed descriptively. Statistical significance between categorical variables was tested by the Chi-Square method using Statistical Package for the
Social Sciences (SPSS).

This study was approved by the ethics commission at the Faculty of Medicine of Udayana University (1638 / UN 14.2.2.VII.14 / LP / 2019).

\section{RESULTS}

Table 1. Characteristic (mean \pm SD) of Elementary School Students in 2018

\begin{tabular}{lccc}
\hline \multicolumn{1}{c}{ Parameters } & Male (n=361) & Female (n= 379) & Total (n=740) \\
\hline Age & $10,6 \pm 0,6$ & $10.5 \pm 0.5$ & $10,6 \pm 0,5$ \\
Weight (kg) & $36,7 \pm 9,7$ & $36.5 \pm 3,2$ & $36,6 \pm 9,3$ \\
Height (m) & $1,4 \pm 0,1$ & $1,4 \pm 0,1$ & $1,4 \pm 0,1$ \\
BMI & $18,5 \pm 3,6$ & $18,1 \pm 3,2$ & $18,3 \pm 3,4$ \\
Running time & $7,0 \pm 1,3$ & $7,6 \pm 1,4$ & $7,3 \pm 1,4$ \\
Nutritional Status (BMI/Age) & & & \\
$\quad$ Very thin & $14(3,9 \%)$ & $13(3,4 \%)$ & $27(3,6 \%)$ \\
$\quad$ Thin & $61(16,9 \%)$ & $83(21,9 \%)$ & $144(19,5 \%)$ \\
$\quad$ Normal & $156(43,2 \%)$ & $185(48,8 \%)$ & $341(46,1 \%)$ \\
$\quad$ Overweight & $123(34,1 \%)$ & $96(25,3 \%)$ & $219(29,6 \%)$ \\
$\quad$ Obese & $7(1,9 \%)$ & $2(0,5 \%)$ & $9(1,2 \%)$ \\
Fitness & & & \\
$\quad$ Less fit & $246(68,1 \%)$ & $229(60,4 \%)$ & $475(64,2 \%)$ \\
Quite fit & $72(20,0 \%)$ & $96(25,3 \%)$ & $168(22,7 \%)$ \\
Fit & $43(11,9 \%)$ & $54(14,3 \%)$ & $97(13,1 \%)$ \\
\hline
\end{tabular}

Table 2. Relationship analysis of gender, age and nutrition status with fitness level

\begin{tabular}{|c|c|c|c|c|c|}
\hline \multirow{2}{*}{ Parameters } & \multicolumn{3}{|c|}{ Fitness Level } & \multirow{2}{*}{ Total } & \multirow{2}{*}{$p$} \\
\hline & Less fit & Quite fit & Fit & & \\
\hline Gender & & & & & $\overline{0,001}$ \\
\hline Male & $246(68,1 \%)$ & $72(19,9 \%)$ & $43(11,9 \%)$ & $361(100,0 \%)$ & \\
\hline Female & $229(60,4 \%)$ & $96(25,3 \%)$ & $54(14,2 \%)$ & $379(100,0 \%)$ & \\
\hline Age (year) & & & & & 0,001 \\
\hline $9-10$ & $195(57,5 \%)$ & $85(25,1 \%)$ & $59(17,4 \%)$ & $339(100,0 \%)$ & \\
\hline $11-12$ & $280(69,8 \%)$ & $83(20,7 \%)$ & $38(9,5 \%)$ & $401(100,0 \%)$ & \\
\hline Nutritional status & & & & & 0,000 \\
\hline Obese & $9(100 \%)$ & $0(0,0 \%)$ & $0(0,0 \%)$ & $9(100 \%)$ & \\
\hline Overweight & $177(80,8 \%)$ & $32(14,6 \%)$ & $10(4,6 \%)$ & $219(100 \%)$ & \\
\hline Normal & $202(59,2 \%)$ & $83(24,3 \%)$ & $56(16,4 \%)$ & $341(100 \%)$ & \\
\hline Thin & $72(50,0 \%)$ & $46(31,9 \%)$ & $26(18,1 \%)$ & $144(100,0 \%)$ & \\
\hline Very thin & $15(55,6 \%)$ & $7(25,9 \%)$ & $5(18,5 \%)$ & $27(100,0 \%)$ & \\
\hline Total & $475(64,2 \%)$ & $\begin{array}{c}168 \\
(22,7 \%)\end{array}$ & $97(13,1 \%)$ & $740(100,0 \%)$ & \\
\hline
\end{tabular}


The results showed the average age of students was $10.6 \pm 0.5$ years and the average body weight was $36.6 \pm 9.3 \mathrm{~kg}$. In this study, no differences were found in the average age and weight of male and female students ( $p>0.05)$. The average height of students was $1.4 \pm 0.1$ meters with a significant difference between male and female students' average height $(\mathrm{p}<0.05)$.

An average BMI of students is $18.3 \pm$ $3.4 \mathrm{~kg} / \mathrm{m}^{2}$ (Table 1.). The proportion of overweight and obesity in students was found to be $29.6 \%$ and $1.2 \%$, respectively. This study also found the proportion of very thin and thin students was $3.6 \%$ and $19.5 \%$, respectively. There was no significant difference between the average BMI in male and female students.

The average running time in fitness measurements was $7.3 \pm 1.4$ minutes. It was found that female students took significantly longer running time than men $(\mathrm{p}<0.05)$. The level of students' fitness was then grouped based on running time and it was found that $64.2 \%$ of students had poor fitness levels, $22.7 \%$ of students had sufficient fitness levels, and $13.1 \%$ of students with good fitness levels.

There was a relationship between sex, age, and nutritional status with fitness for elementary students (Table 2.). The results found $100 \%$ of obese students and $80.8 \%$ of overweight students had less fitness level. The table also shows that thin and very thin students have less fitness. However, this study also found that $59.2 \%$ of students with normal nutritional status had fewer fitness levels.

\section{DISCUSSION}

This study found that $64.2 \%$ of elementary students were at a poor level of fitness and only $13.1 \%$ at a good level of fitness. Fitness measurements were carried out using the single test method which is a submaximal measurement method. The validity of a fitness test using the submaximal method is indeed less than the maximum method measurement such as the Multi- stage Fitness Test (MFT), balke test, or cooper test. Individuals do the test longer when conducting maximum measurement so that physical performance will be more leverage. Whereas submaximal measurements are made with a certain distance benchmark but do not issue maximum power.

In this study, we also found that male students were less fit than female students. This result is in line with previous studies, which showed that more boys did not pass the fitness standard compared to girls $(\mathrm{AOR}=1,710 ; 95 \% \mathrm{CI}=1,708-1,712)^{14}$. Before puberty, fitness in boys and girls is not much different. But after that, the average woman has a lower level of fitness than men. This might be caused by smaller muscle mass and greater fat mass in women than in men ${ }^{19}$.

It is found that there was a relationship between sex, age, and nutritional status marked by BMI/Age with fitness for elementary school students aged 10-12 years. This finding is in line with research conducted in Serbia in 2011 which stated a strong negative relationship between aerobic fitness and body fatness ${ }^{15}$.

A systematic review found that there is a relationship between being overweight and physical fitness ${ }^{12}$. The relationship between body mass index and physical fitness is generally nonlinear (parabolic) in adolescents aged 10-17 years ${ }^{16}$.

From the results, it can be seen that poor physical fitness is not only observed in children with obesity and overweight but also those with normal nutritional status, thin and very thin children. These results are in line with research conducted in Brazil which found that the reduction in physical fitness was not only seen in overweight children but also those with normal weight ${ }^{17}$. It has occurred because nutritional status is not the only strong predictor to determine the level of fitness among school children. Physical activity is also another related factor to determine fitness level.

It is often assumed that physical 
activity is causally related to the level of fitness. Regular activities reduce the workload of the hearth and have several direct effects on the hearth. A fit individual has a lower heart rate during physical activities, training/exercise, or rest ${ }^{18}$. The results showed that individuals who were more physically active tended to have a good level of fitness ${ }^{19}$. Another study also showed that fitness is positively related to physical activity. Therefore, it is suggested that increasing the level of physical activity can be an effective measure for increasing fitness levels among adolescents ${ }^{20}$.

To achieve maximum academic and non-academic achievement, optimization of growth and development among school-age children needs to be done. One of the important things to note is the condition of physical fitness level ${ }^{11}$. In its implementation, this study has several limitations. This study cannot explain the causal relationship. Selection bias might be occurred because of non-random sampling during the respondent selection for fitness measurements. The fitness measurement method used is an indirect measurement and the measurement results depend on the level of motivation of individuals in running 1200 meters distance. It is difficult to measure whether students apply maximum effort in conducting this test. This study also did not measure the level of physical activity which is a predictor of the fitness level.

\section{CONCLUSION}

It is concluded that there is a significant relationship between age, sex, and nutritional status with fitness in elementary school students. Less fit status is not only found in students with overweight and obese but also students with low nutritional status. It is recommended to improve the nutritional status of elementary school students to improve their fitness.

\section{ACKNOWLEDGMENT}

We would like to thank the Head of Bali Provincial Health Service and the
Head of Integrated Service Unit of Traditional Health Medicine at Bali Provincial Health Service.

\section{REFERENCES}

1. Lee DC et al. Leisure-Time Running Reduces All-Cause and Cardiovascular Mortality Risk. J Am Collage Cardiol. 2014;64(5).

2. Eduardo Rossato de Victo $G$ et al. Lifestyle indicators and cardiorespiratory fitness in adolescents.2017;35 (1):61-8.

3. Morita N, Nakajima $T$, Okita K, Ishihara T, Sagawa M YK. Relationships among fitness, obesity, screen time and academic achievement in Japanese adolescents. Physiol Behav [Internet]. 2016;163:161-6. Available from: http://dx.doi.org/10.1016/ j.physbeh.2016.04.055

4. Chen S, Gu X. Effects of cardiorespiratory fitness and weight status on knowledge of physical activity and fitness, attitude toward physical education, and physical activity. BMC Public Health. 2018;18(1):17.

5. Gerson GL, Bracco MM, Matsudo VKR, Fisberg M. Cardiorespiratory fitness and nutritional status of schoolchildren: 30-year evolution. J Pediatr (Rio J) [Internet]. 2013;89 (4):366-73. Available from: http:// dx.doi.org/10.1016/ j.jpedp. 201212.008

6. Luis G, Ferrari DM, Maia M, Rodrigues VK. Cardiorespiratory fitness and nutritional status of schoolchildren: 30-year evolution. J Pediatr. 2013;89(4):366-73.Available from: http://dx.doi.org/10.1016/ j.jped. 2012.12.006

7. Ashkan et al. Health Effects of Overweight and Obesity in 195 Countries over 25 Years. N Engl J Med. 2017;377 No 1:13-27. 


\section{WMJ (Warmadewa Medical Journal), Vol. 5 No. 1, Mei 2020, Hal. 21}

8. Labree W, Van De Mheen D, Rutten F, Rodenburg G, Koopmans G, Foets M. Differences in overweight and obesity among children from migrant and native origin: The role of physical activity, dietary intake, and sleep duration. PLoS One. 2015;10(6):112 .

9. $\mathrm{Ng} \mathrm{M}$, Fleming $\mathrm{T}$, Robinson $\mathrm{M}$, Thomson B, Graetz N. Global, regional and national prevalence of overweight and obesity in children and adults 1980-2013: A systematic analysis. Lancet. 2014;384 (9945):766-81.

10. Kemenkes. Laporan Nasional Riskesdas 2018. Jakarta: Lembaga Penerbit Badan Penelitian dan Pengembangan Kesehatan; 2019.

11. Kemenkes RI. Direktorat Kesehatan Kerja dan Olahraga. Direktorat Kesehatan Kerja dan Olahraga. 2017.

12. Rauner A, Mess F, Woll A. The relationship between physical activity, physical fitness and overweight in adolescents a systematic review of studies published in or after 2000. BMC Pediatr. 2013;13:19:1-9.

13. Kemenkes. Panduan pembinaan kebugaran jasmani bagi peserta didik melalui UKS/M. 2019;1-69.

14. Fan X, Cao ZB. Prevalence of physical fitness in Chinese school-aged children: Findings from the 2016 Physical Activity and Fitness in China-The Youth Study. J Sport Heal Sci [Internet]. 2017;6(4):388-94. Available from: https:// doi.org /10.1016/j.jshs.2017.09.003
15. Ostojic SM, Stojanovic MD, Stojanovic V, Maric J, Njaradi N. Correlation between Fitness and Fatness in 6-14-year Old Serbian School Children. J Heal Popul Nutr. 2011;29(1):53-60.

16. Lopes VP, Malina RM, GomezCampos R, Cossio-Bolaños M, Arruda $\mathrm{M}$ de, Hobold $\mathrm{E}$. Body mass index and physical fitness in Brazilian adolescents. J Pediatr (Rio J). 2018;(xx).

17. Luis G, Ferrari DM, Keihan V, Matsudo R, Fisberg M. REVISTA PAULISTA Changes in physical fitness and nutritional status of schoolchildren in a period of 30 years ( 1980-. Rev Paul Pediatr (English Ed [Internet]. 2015;33 (4):415-22. Available from: http:// dx.doi.org/10. 1016/ j.rppede.2015.03.001

18. Sharkley. Kebugaran dan Kesehatan. Eri Desmarini Nasution P, editor. Jakarta: Rajagrafindo Persada; 2016.

19. Pahkala K, Hernelahti M, Heinonen OJ, Raittinen P, Hakanen M, Lagström $\mathrm{H}$, et al. Body mass index , fi tness and physical activity from childhood through adolescence. Br J Sports Med. 2013;47:71-7.

20. Aires L, Pratt M, Lobelo F, Santos RM, Santos MP, Mota J. Associations of Cardiorespiratory Fitness in Children and Adolescents With Physical Activity, Active Commuting to School, and Screen Time. J Phys Act Heal. 2011;8(Suppl 2):198 -205 . 